\title{
Article \\ Design of PG-Surfactants Bearing Polyacrylamide Polymer Chain to Solubilize Membrane Proteins in a Surfactant-Free Buffer
}

\author{
Taro Shimamoto $^{1}$, Tatsuki Nakakubo ${ }^{1}$, Tomoyasu Noji ${ }^{2}$, Shuhei Koeda ${ }^{3}$, Keisuke Kawakami ${ }^{4,+}$, Nobuo Kamiya ${ }^{4}$ \\ and Toshihisa Mizuno $1,3, * \mathbb{D}$
}

1 Department of Life Science and Applied Chemistry, Graduate School of Engineering, Nagoya Institute of Technology, Gokiso-cho, Showa-ku, Nagoya, Aichi 466-8555, Japan; t.shimamoto.444@nitech.jp (T.S.); t.nakakubo.266@stn.nitech.ac.jp (T.N.)

2 Research Center for Advanced Science \& Technology, The University of Tokyo, 4-6-1 Komaba, Meguro-ku, Tokyo 153-8904, Japan; tnoji@protein.rcast.u-tokyo.ac.jp

3 Department of Nanopharmaceutical Sciences, Graduate School of Engineering, Nagoya Institute of Technology, Gokiso-cho Showa-ku, Nagoya, Aichi 466-8555, Japan; s.b.shuhei0316@gmail.com

4 The OCU Advanced Research Institute for Natural Science \& Technology (OCARINA), Osaka City University, 3-3-138 Sugimoto-cho, Sumiyoshi, Osaka 558-8585, Japan; keisuke.kawakami@riken.jp (K.K.); rss78535@yahoo.co.jp (N.K.)

* Correspondence: toshitcm@nitech.ac.jp; Tel.: +81-52-735-5237

+ Present address: Biostructural Mechanism Laboratory, RIKEN SPring-8 Center, 1-1-1 Kouto, Sayo, Hyogo 679-5148, Japan.

check for updates

Citation: Shimamoto, T.; Nakakubo, T.; Noji, T.; Koeda, S.; Kawakami, K.; Kamiya, N.; Mizuno, T. Design of PG-Surfactants Bearing Polyacrylamide Polymer Chain to Solubilize Membrane Proteins in a Surfactant-Free

Buffer. Int. J. Mol. Sci. 2021, 22, 1524. https://doi.org/10.3390/ijms22041524

Academic Editor: Daniela Marasco Received: 4 December 2020

Accepted: 1 February 2021

Published: 3 February 202

Publisher's Note: MDPI stays neutral with regard to jurisdictional claims in published maps and institutional affiliations.

Copyright: (c) 2021 by the authors. Licensee MDPI, Basel, Switzerland This article is an open access article distributed under the terms and conditions of the Creative Commons Attribution (CC BY) license (https:// creativecommons.org/licenses/by/ $4.0 /)$

\begin{abstract}
The development of techniques capable of using membrane proteins in a surfactant-free aqueous buffer is an attractive research area, and it should be elucidated for various membrane protein studies. To this end, we examined a method using new solubilization surfactants that do not detach from membrane protein surfaces once bound. The designed solubilization surfactants, $\mathrm{DKDKC}_{12} \mathrm{~K}_{-\mathrm{PA}}(n=5,7$, and 18), consist of two parts: one is the lipopeptide-based solubilization surfactant part, $\mathrm{DKDKC}_{12} \mathrm{~K}$, fand the other is the covalently connected linear polyacrylamide (PA) chain with different $M_{\mathrm{W}}$ values of 5,7 , or $18 \mathrm{kDa}$. Intermolecular interactions between the PA chains in $\mathrm{DKDKC}_{12} \mathrm{~K}_{-} \mathrm{PA}_{n}$ concentrated on the surfaces of membrane proteins via amphiphilic binding of the $\mathrm{DKDKC}_{12} \mathrm{~K}$ part to the integral membrane domain was observed. Therefore, $\mathrm{DKDKC}_{12} \mathrm{~K}_{-}-\mathrm{PA}_{n}$ $(n=5,7$, and 18$)$ could maintain a bound state even after removal of the unbound by ultrafiltration or gel-filtration chromatography. We used photosystem I (PSI) from Thermosynecoccus vulcanus as a representative to assess the impacts of new surfactants on the solubilized membrane protein structure and functions. Based on the maintenance of unique photophysical properties of PSI, we evaluated the ability of $\mathrm{DKDKC}_{12} \mathrm{~K}_{-} \mathrm{PA}_{n}(n=5,7$, and 18$)$ as a new solubilization surfactant.
\end{abstract}

Keywords: solubilization surfactants; membrane protein; surfactant-free; photosystem I; polyacrylamide

\section{Introduction}

One-third of natural proteins are classified as membrane proteins, and these have crucial roles in various biological events occurring at cell membranes. Photosynthesis is one such membrane-mediated event that participates in different unique membrane proteins. In higher plants and cyanobacteria, photosystem I (PSI) and photosystem II (PSII), integrated in thylakoid membranes, play pivotal roles in generating reductive electrons from water using sunlight [1]. In natural thylakoid membranes, the generated reductive electrons are used for NADPH synthesis via ferredoxin $\mathrm{NADP}^{+}$oxidoreductase (FNR) [2], but exchanging this reductive enzyme to other reductive enzymes or catalysts the artificial photosynthesis systems in vitro and in vivo were recently examined [3]. If the reductive electrons are directly poured into the electrode, it leads to solar cell construction [4]. To 
combine PSI with reductive enzymes or catalysts, such as molecular metal catalysts [5], Pt nanoparticles [6], or hydrogenases [7] in vitro, direct modification via adsorption or chemical bonds [8] and indirect electrochemical connection via electrodes or metal nanoparticles [9] have been studied. However, the construction of more sophisticated artificial photosynthesis systems [10] consisting of PSI, reductive catalysts, and electron transfer mediators, and sacrificial reductants using solubilization surfactants for membrane proteins to treat PSI in an aqueous buffer could become a decisive hindrance; if PSI could be treated in an aqueous buffer similar to water-soluble proteins, it would allow flexible design of molecular circuits using PSI. The techniques able to treat membrane proteins in an aqueous buffer, identical to water-soluble proteins, such as the construction of various semi-artificial molecular sensors and drug screening samples consisting of different natural membrane proteins is also an interesting research area [11].

Some methods capable of treating membrane proteins in a surfactant-free buffer have been reported so far. Its developments have particular relevance to structural analytical techniques of membrane proteins using cryo-microscopy [12] and multi-dimensional NMR [13]. For structural analysis by cryo-microscopy, sample preparation of membrane proteins with fewer contaminants is indispensable for obtaining high-quality TEM images for structural analysis. Some new surfactants such as lauryl maltose neopentyl glycol [14] and amphipols [15] have a high affinity for membrane proteins; therefore, the unbound surfactants are known to separate without precipitation by dialysis or ultrafiltration. On the other hand, some amphiphilic block copolymers are known to extract membrane proteins directly from bio-membranes $[16,17]$. By using the deuterated membrane proteins expressed in E. coli cell membranes, structural analysis of membrane proteins solubilized with these copolymers using multi-dimensional NMR has been reported [18]. Considering these situations, further developments of new surfactants or techniques capable of treating membrane proteins in surfactant-free buffers are expected. However, developments in these techniques are still limited to date.

Meanwhile, we recently studied Gemini-type peptide surfactants, PG-surfactants [19-23]. The basic molecular scaffold of PG-surfactants consists of three constituents: the linker peptide from to 3-5 residues $(X)$, two alkylamidomethyl-modified Cys residues at both sides of the linker peptide, and the peripheral peptides ( $\mathrm{Y}$ and $\mathrm{Z}$ ) at the $\mathrm{N}$ - and $\mathrm{C}$-terminal sides of the alkylamidomethyl-modified Cys residues (Figure 1a). From a set of screenings on hydrophilic peptide sequences at $X, Y$, and Z, we found that two PG-surfactants, $\mathrm{DKDKC}_{12} \mathrm{~K}$ and $\mathrm{DKDKC}_{12} \mathrm{D}$, were able to function as solubilization surfactants for membrane proteins [20]. Furthermore, by the tandem connection of the -Cys $\left(\mathrm{C}_{12}\right)$-Asp-Lys-Asp-LysCys $\left(\mathrm{C}_{12}\right)$ - units in $\mathrm{DKDKC}_{12} \mathrm{~K}$ and $\mathrm{DKDKC}_{12} \mathrm{D}$ via flexible (Gly $)_{4}$ linkers in one molecule, we succeeded in designing the high molecular weight (MW) solubilization surfactants, Bis$\mathrm{D}_{3}$-DKDKC 12 (MW $\sim 3 \mathrm{kDa}$ ), Bis-K ${ }_{3}-\mathrm{DKDKC}_{12}$ (MW $\sim 3 \mathrm{kDa}$ ), and Tris- $\mathrm{D}_{3}-\mathrm{DKDKC}_{12}$ (MW $\sim 4.3 \mathrm{kDa}$ ) [21]. Interestingly, an increase in $\mathrm{Mw}$ enhanced the affinity between membrane proteins and surfactants, thereby allowing effective solubilization, even for lower concentration ranges $(<0.0005 \mathrm{wt} \%)$. In this study, by conjugating a hydrophilic polymer unit with ${ }_{D K D K C}{ }_{12} \mathrm{~K}$, we designed different types of high-Mw surfactants, which can function as a solubilization surfactant for membrane proteins (Figure 1b). We hypothesized that due to the high affinity between polymer chains concentrated on membrane surfaces, these surfactants would not detach once bound to membrane protein surfaces, thereby generating a method to treat membrane proteins in the surfactant-free buffer. In this case, because the attached polymer chains would also interact with membrane protein surfaces, to choose hydrophilic polymers, giving less impact on tertiary structure of membrane proteins, is necessary. Therefore, as a hydrophilic polymer, in this study, we chose poly(acrylamide) (PA). We synthesized PA with different $\mathrm{MW}\left(M_{\mathrm{n}}=5,7\right.$, and $\left.18 \mathrm{kDa}\right)$ and characterized the solubilization ability of the conjugates with $\mathrm{DKDKC}_{12} \mathrm{~K}$. DKDKC ${ }_{12} \mathrm{~K}-\mathrm{PA}_{n}(n=5,7$, and 18 , Figure $1 \mathrm{~b}$ ), and the PA units were introduced at the $\mathrm{Y}$ position of $\mathrm{DKDKC}_{12} \mathrm{~K}$. 
(a)

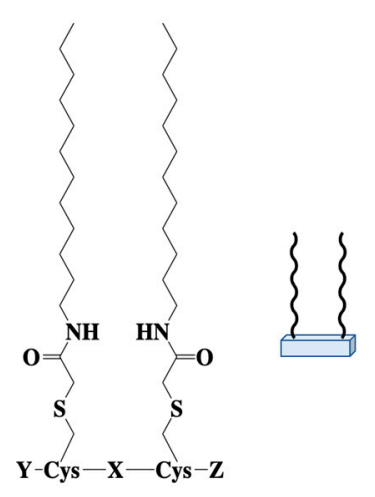

(b)

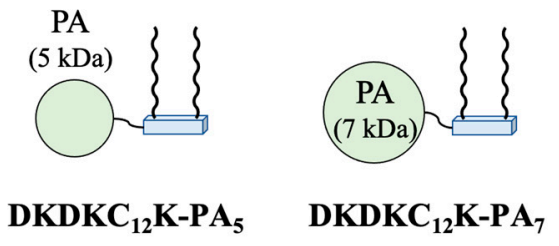

Figure 1. Chemical structure of PG-surfactants and schematic illustration of their conjugates with polyacrylamide (PA) (a) Chemical structure of PG-surfactants with $\mathrm{C}_{12}$ alkyl chains (X: linker peptide, Y, Z: peripheral peptide). (b) Schematic illustration of the PA-appended solubilization surfactants, $\mathrm{DKDKC}_{12} \mathrm{~K}_{-} \mathrm{PA}_{n}\left(n=5,7\right.$, and 18). $\mathrm{X}$ is -Asp-Lys-Asp-Lys and $\mathrm{Z}$ is $-\mathrm{NH}_{2}$. Y is Ac-Cys-Lys-, in which PA unit was covalently connected to side chain of Cys via S-S bond.

\section{Results and Discussion}

2.1. Design of Solubilization Surfactants Bearing Linear Polyacrylamide (PA) Polymer Chain

To synthesize the polymer-appended $\mathrm{DKDKC}_{12} \mathrm{~K}$, we separately synthesized the hydrophilic polymer and the surfactant parts and then joined them. For the surfactant part, we chose the PG-surfactant $\mathrm{DKDKC}_{12} \mathrm{KC}$, in which one Cys residue was added to the $\mathrm{N}$-terminal side of $\mathrm{DKDKC}_{12} \mathrm{~K}$ (Figure $\mathrm{S1}$ ). Because $\mathrm{DKDKC}_{12} \mathrm{~K}$ has a higher molecular weight (MW 1330) than the general low MW solubilization surfactants such as $n$-octyl- $\beta$-Dglucopyranoside ( $\beta$-OG, MW 292) and $n$-dodecyl- $\beta$-D-maltopyranoside ( $\beta$-DDM, MW 511), it was tolerant of introducing other functional groups to the $\mathrm{N}$ - or $\mathrm{C}$-terminal of the same molecule without losing its original solubilization function for membrane proteins [20,23]. We expected that $\mathrm{DKDKC}_{12} \mathrm{~K}$ would also conjugate hydrophilic polymers without losing the original solubilization function. An additional Cys residue was used for conjugation with the hydrophilic polymer part.

For the hydrophilic polymer part, we chose polyacrylamide (PA) in this study. As PA is used as a gel material for protein electrophoresis [24] and immobilization substrates for proteins [25], choosing it as a polymer for solubilization surfactants would be reasonable to reduce structural damage to membrane proteins. To examine the impact of $M_{n}$ on the solubilization functions of polymer-appended $\mathrm{DKDKC}_{12} \mathrm{~K}$, we synthesized PA with different $M_{\mathrm{n}}$ values of 5, 7, and $18 \mathrm{kDa}$ by reversible addition-fragmentation chain transfer (RAFT) polymerization [26]. Further, to conjugate with $\mathrm{DKDKC}_{12} \mathrm{KC}$, the RAFT initiator containing the dithiopyridyl (DTP) group, BSTP pyridyl disulfide [27] was used for the synthesis of PA bearing the DTP groups at the terminal, PA $_{n}$-DTP $(n=5,7$, and 18, Scheme 1). The synthesized $\mathrm{PA}_{n}$-DTPs were subjected to gel permeation chromatography (GPC), and the calculated $M_{\mathrm{n}} S$ and polydispersity indexes (PDI) are listed in Table 1.

Joining of DKDKC ${ }_{12} \mathrm{KC}$ and $\mathrm{PA}_{n}$-DTA via S-S bond (Scheme 2) was performed according to Scheme 2, and the target conjugates were purified by reverse-phase highperformance liquid chromatography (RP-HPLC, Figures S2-S4). Compound identification was performed by dividing the PA and $\mathrm{DKDKC}_{12} \mathrm{KC}$ units again via reducing the isolated conjugates using DTT, and RP-HPLC identified each divided unit. Hereafter, the polymer-appended $\mathrm{DKDKC}_{12} \mathrm{~K} s$ were named $\mathrm{DKDKC}_{12} \mathrm{~K}_{-} \mathrm{PA}_{n}(n=5,7,18)$. 


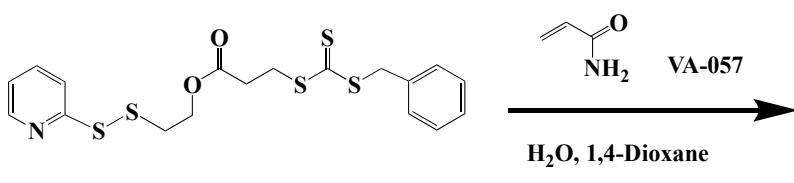

BSTP pyridyl disulfide

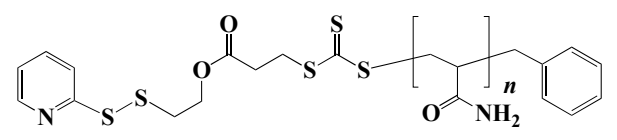

$\mathbf{P A}_{n}$-DTP

$(n=5,7,18)$

Scheme 1. Synthesis of polyacrylamide (PA) with dithiopyridyl unit $\left(\mathrm{PA}_{n}-\mathrm{DTP}, n=5,7,18\right)$ via RAFT polymerization.

Table 1. Summary of $M_{n}$ and PDI off $\operatorname{PA}_{n}$-DTP $(n=5,7$, and 18).

\begin{tabular}{cc}
\hline $\mathbf{P A}_{\boldsymbol{n}}$-DTP & $\boldsymbol{M}_{\mathbf{n}} \mathbf{( P D I}^{\mathbf{a}}$ \\
\hline $\mathrm{PA}_{5}$-DTP & $4500(1.19)$ \\
\hline $\mathrm{PA}_{7}$-DTP & $6900(1.29)$ \\
\hline $\mathrm{PA}_{18}$-DTP & $17,800(1.14)$
\end{tabular}

${ }^{\mathrm{a}} \mathrm{M}_{\mathrm{n}}$ and PDI of the polyacrylamide part determined using polyethylene glycol standard.
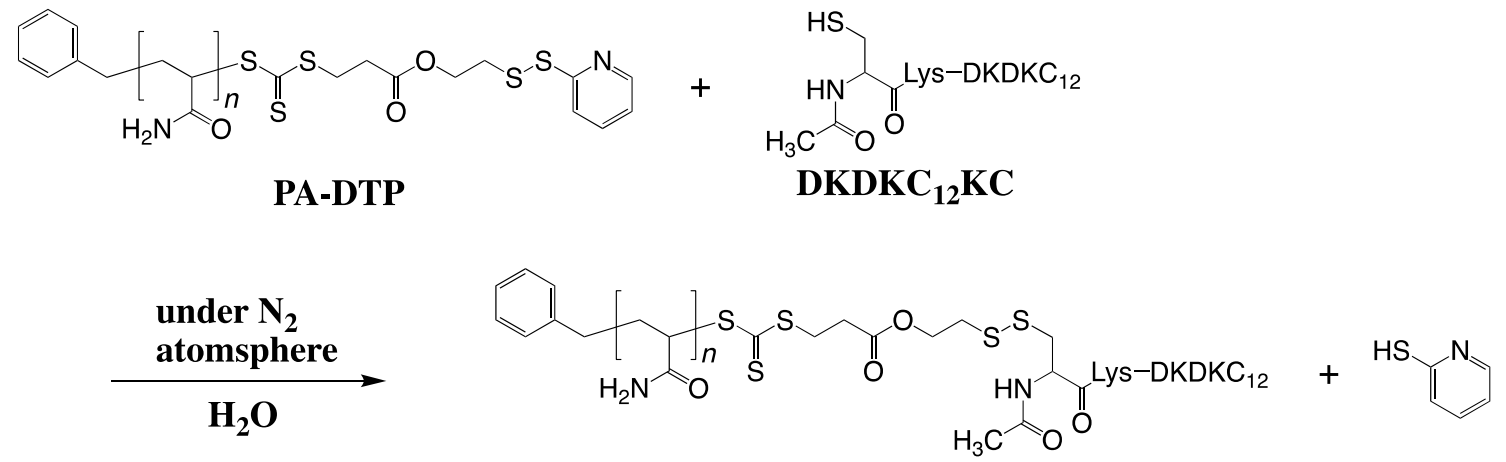

$\mathrm{DKDKC}_{12} \mathrm{~K}-\mathrm{PA}_{n}$

Scheme 2. Synthesis of $\mathrm{DKDKC}_{12} \mathrm{~K}_{-} \mathrm{PA}_{n}(n=5,7,18)$.

Before studies on PSI solubilization using new surfactants, we first characterized the fundamental micelle formation properties of $\mathrm{DKDKC}_{12} \mathrm{~K}-\mathrm{PA}_{n}$ based on dynamic light scattering (DLS) measurements and critical aggregation concentrations (CACs) (Table 2). With an increase in surfactant concentration, the fluorescence intensity of ANS in a buffer increased with a single inflection point. The plots of $F_{478}$ vs. surfactant concentration are shown in Figure S5. Since the concentrations at this inflection point, evaluated from the cross point of double linear-fittings, correspond to the $\mathrm{CAC}$ of the amphiphilic molecules, we could determine the CACs (mol/L) of DKDKC ${ }_{12} \mathrm{~K}_{-} \mathrm{PA}_{5}, \mathrm{DKDKC}_{12} \mathrm{~K}_{-}-\mathrm{PA}_{7}$, and DKDKC ${ }_{12} \mathrm{~K}-$ $\mathrm{PA}_{18}$ and they were found to be 51,46 , and $47 \mu \mathrm{M}$, respectively; the CACs with mol/L as a unit were calculated from $\mathrm{CAC}$ with $\mathrm{wt} \%$ as a unit by the assumption of $\mathrm{MW}$ of $\mathrm{DKDKC}_{12} \mathrm{~K}_{-} \mathrm{PA}_{5}, \mathrm{DKDKC}_{12} \mathrm{~K}-\mathrm{PA}$, and $\mathrm{DKDKC}_{12} \mathrm{~K}-\mathrm{PA}_{18}$, as 5900, 8300, and 19,200, respectively. The modification of PA to $\mathrm{DKDKC}_{12} \mathrm{~K}$ hampered micelle formation between the $\mathrm{DKDKC}_{12} \mathrm{~K}$ moieties, but the maintenance of micelle formation property was observed for all DKDKC ${ }_{12} \mathrm{~K}_{-} \mathrm{PA}_{n}$. The DLS profiles of $0.1 \mathrm{wt} \% \mathrm{DKDKC}_{12} \mathrm{~K}-\mathrm{PA}_{5}, \mathrm{DKDKC}_{12} \mathrm{~K}-\mathrm{PA}_{7}$, and $\mathrm{DKDKC}_{12} \mathrm{~K}_{-} \mathrm{PA}_{18}$ in phosphate buffer gave a single peak at 13, 25, and $29 \mathrm{~nm}$, respectively, and an apparent increase in micelle diameters was observed with the increase in $M_{n}$ of the 
PA unit. These data also support the idea that $\mathrm{DKDKC}_{12} \mathrm{~K}$ units in $\mathrm{DKDKC}_{12} \mathrm{~K}-\mathrm{PA}_{n}$ could form micelles similar to those of $\mathrm{DKDKC}_{12} \mathrm{~K}$ [20] even after the introduction of PA units.

Table 2. CAC and hydrodynamic diameter $(d, \mathrm{~nm})$ of $\mathrm{DKDKC}_{12} \mathrm{~K}-\mathrm{PA}{ }_{n}$ in $100 \mathrm{mM}$ phosphate buffer (pH 7).

\begin{tabular}{cccc}
\hline & CAC $(\mathbf{w t} \%)$ & CAC $(\mu \mathbf{M})$ & $d(\mathbf{n m})^{\mathbf{a}}$ \\
\hline DKDKC $_{12} \mathrm{~K}$ & - & $8.3^{\mathrm{b}}$ & $6^{\mathrm{b}}$ \\
\hline $\mathrm{DKDKC}_{12} \mathrm{~K}-\mathrm{PA}_{5}$ & 0.030 & $51^{\mathrm{c}}$ & 13 \\
$\mathrm{DKDKC}_{12} \mathrm{~K}^{\mathrm{P}}$ & 0.038 & $46^{\mathrm{c}}$ & 25 \\
$\mathrm{DKDKC}_{12} \mathrm{~K}^{\mathrm{P}}$ & 0.090 & $47^{\mathrm{c}}$ & 29 \\
\hline
\end{tabular}

a The concentration of each was set to $0.1 \mathrm{wt} \% .{ }^{\mathrm{b}}$ Referred from ref. $21 .{ }^{\mathrm{c}}$ The CACs with mol/L as a unit were calculated from CAC with $w \mathrm{t} \%$ as a unit by the assumption of $\mathrm{MW}$ of $\mathrm{DKDKC}_{12} \mathrm{~K}_{-} \mathrm{PA}_{5}, \mathrm{DKDKC}_{12} \mathrm{~K}-\mathrm{PA}_{7}$, and $\mathrm{DKDKC}_{12} \mathrm{~K}_{-} \mathrm{PA} 18$, as 5900, 8300, and 19,200, respectively.

\subsection{Solubilization of Photosystem I from Thermosynecoccus (T.) Vulcanus by $D K D K C_{12} K-P A_{n}$ $(n=5,7$, and 18)}

To evaluate the solubilization ability of $\mathrm{DKDKC}_{12} \mathrm{~K}-\mathrm{PA}_{n}$ for membrane proteins, in this study, we used PSI from T. vulcanus as a representative membrane protein. PSI is a trimeric supramolecular pigment-protein complex (total MW of $1068 \mathrm{kDa}$ ); each PSI unit includes 12 protein subunits, 96 chlorophyll a (Chl a) molecules, and 3 [4Fe-4S] clusters [28]. In higher plants and cyanobacteria, it exists in thylakoid membranes and participates in the reductive side light reaction. Because surfactants have unique photophysical properties derived from the hierarchical supramolecular organization of these components, this protein could be used as a probe to evaluate impacts of surfactants on protein structure and functions from impacts on their photophysical properties $[20,21]$. The PSI samples solubilized with the buffer K2 (40 mM HEPES- NaOH (pH 7.8), $100 \mathrm{mM} \mathrm{NaCl}, 15 \mathrm{mM}$ $\mathrm{CaCl}_{2}$, and $15 \mathrm{mM} \mathrm{MgCl}$ ) containing $0.1 \mathrm{wt} \% \mathrm{DKDKC}_{12} \mathrm{~K}-\mathrm{PA}_{n}$ were prepared by the surfactant-exchange method as previously reported [20]. The observed absorption spectra at $298 \mathrm{~K}$ and the fluorescence spectra at $77 \mathrm{~K}$ are shown in Figure 2. Absorption spectra in the 300-800 nm range mainly originated from 96 molecules of antenna Chl a, coordinated in PsaA and PsaB subunits at PSI integral membrane domain. Therefore, maintenance of the absorption spectrum could strongly suggest maintenance of the tertiary structure, especially at the integral membrane domain. The fluorescence spectrum of PSI in the $650-800 \mathrm{~nm}$ range at $77 \mathrm{~K}$ corresponds to the formation of the red chlorophyll state by $\mathrm{Chl}$ a molecules in the PsaA and PsaB scaffolds. This fluorescence is also a unique characteristic of $\mathrm{Chl}$ a molecules in native PSI. Therefore, maintenance of the fluorescence spectrum also supports the maintenance of the tertiary structure at the integral membrane domain of PSI. As shown in Figure 2, all PSI samples, solubilized by $0.1 \mathrm{wt} \% \mathrm{DKDKC}_{12} \mathrm{~K}^{\mathrm{PA}}{ }_{n}$, showed similar spectra using $0.1 \mathrm{wt} \% \beta-\mathrm{DDM}$ as a solubilization surfactant (control of the native state), suggesting that all DKDKC ${ }_{12} \mathrm{~K}-\mathrm{PA}_{n}$ showed successful solubilization of PSI without denaturation, similar to the parent PG-surfactants, DKDKC ${ }_{12} \mathrm{~K}$.

Upon using general low MW solubilization surfactants, membrane proteins are solubilized in a buffer by covering the hydrophobic surfaces of the membrane integral domain with surfactant micelles. Therefore, if the surfactant concentration is less than the critical micelle concentration (CMC), most surfactants cannot form micelles and cannot solubilize membrane proteins in a buffer. However, if the affinity of surfactants to membrane proteins or between surfactants concentrated onto membrane protein surfaces was sufficiently high, the necessary number of surfactant molecules able to solubilize was not governed under surfactant CMCs. In short, if the affinity between DKDKC ${ }_{12} \mathrm{~K}_{-} \mathrm{PA}_{n}$ and PSI or intermolecular interactions between the introduced PA chains in $\mathrm{DKDKC}_{12} \mathrm{~K}-\mathrm{PA}_{n}$ is high enough, the isolation of the conjugates of PSI and DKDKC ${ }_{12} \mathrm{~K}_{-} \mathrm{PA}_{n}$ was probable. Therefore, we attempted to isolate the conjugates by separation of unbound $\mathrm{DKDKC}_{12} \mathrm{~K}-\mathrm{PA}_{n}$ from the PSI sample. Using an ultrafiltration unit (cut-off MW: $100 \mathrm{kDa}$ ), we removed the unbound $\mathrm{DKDKC}_{12} \mathrm{~K}-$ $\mathrm{PA}_{n}$ from the PSI samples (theoretical concentration of $\mathrm{DKDKC}_{12} \mathrm{~K}-\mathrm{PA} n$ after ultrafiltration 
was less than $0.00001 \mathrm{wt} \%$ ), prepared in the buffer $\mathrm{K} 2$ with $0.1 \mathrm{wt} \% \mathrm{DKDKC}_{12} \mathrm{~K}-\mathrm{PA}{ }_{n}$. As surfactant concentrations decreased to less than $0.00001 \mathrm{wt} \%$, the reference PSI sample solubilized with $0.1 \mathrm{wt} \% \beta$-DDM became insoluble (Figure $3 \mathrm{~d}$ ). However, those with $\mathrm{DKDKC}_{12} \mathrm{~K}_{-} \mathrm{PA}_{n}$ maintained good solubility. These samples were further subjected to gel permeation chromatography (GPC) using buffer $\mathrm{K} 2$ without including any solubilization surfactants, and the DKDKC ${ }_{12} \mathrm{~K}_{-}-\mathrm{PA}_{n}$-bound PSIs were finally obtained as a water-soluble conjugate in a surfactant-free buffer (Figure $3 \mathrm{a}-\mathrm{c}$ ). Upon this surfactant-free condition, the

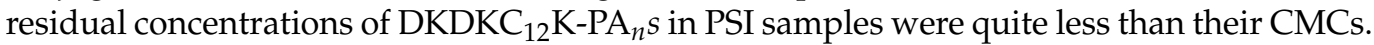
With considering that hydrophobic interaction of $\mathrm{DKDKC}_{12} \mathrm{~K}-\mathrm{PA}_{n} s$ to the hydrophobic surfaces of PSI is mainly originated only from two C12 chains in $\mathrm{DKDKC}_{12} \mathrm{~K}-\mathrm{PA}_{n} s$, this stable binding of $\mathrm{DKDKC}_{12} \mathrm{~K}-\mathrm{PA}{ }_{n} s$ to PSI molecules could be occurred by effective intermolecular interactions between the PA chains in $\mathrm{DKDKC}_{12} \mathrm{~K}-\mathrm{PA}_{n} s$.

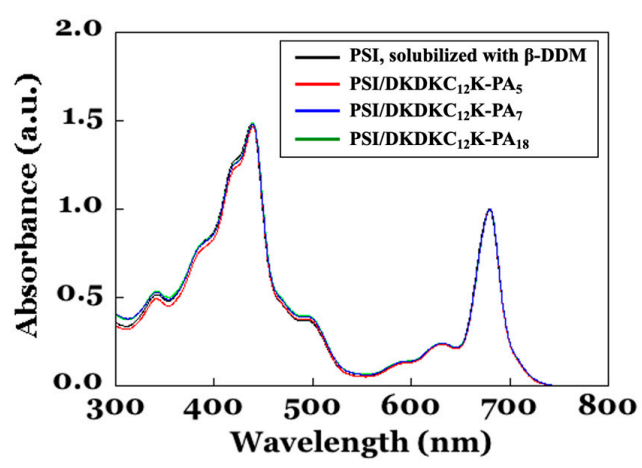

(a)

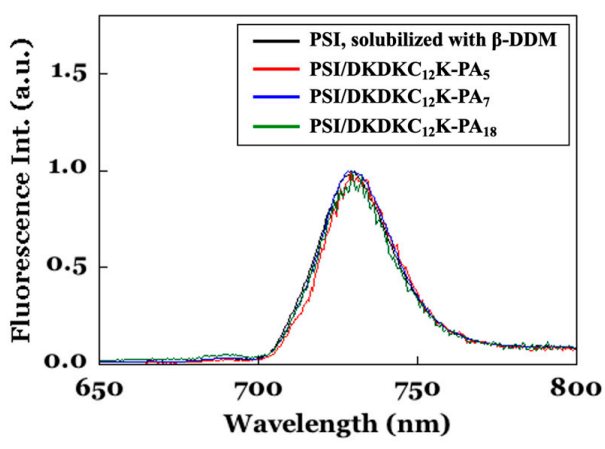

(b)

Figure 2. Absorption and fluorescence spectra of PSI, solubilized with $0.1 \mathrm{wt} \% \beta$-DDM, or conjugated with $\mathrm{DKDKC}_{12} \mathrm{~K}_{-} \mathrm{PA} \mathrm{A}_{n}$ $(n=5,7,18)$. (a) Absorption spectra of PSI, solubilized with $0.1 \mathrm{wt} \% \beta$-DDM (black), DKDKC ${ }_{12} \mathrm{~K}_{-} \mathrm{PA}_{5}$ (red), $\mathrm{DKDKC}_{12} \mathrm{~K}-\mathrm{PA}{ }_{7}$ (blue), and $\mathrm{DKDKC}_{12} \mathrm{~K}_{-} \mathrm{PA}_{18}$ (green). (b) Florescence spectra of PSI, solubilized with $0.1 \mathrm{wt} \% \beta$-DDM (black), DKDKC ${ }_{12} \mathrm{~K}$ $\mathrm{PA}_{5}$ (red), $\mathrm{DKDKC}_{12} \mathrm{~K}-\mathrm{PA}_{7}$ (blue), and $\mathrm{DKDKC}_{12} \mathrm{~K}-\mathrm{PA}_{18}$ (green).

(a)

(b)

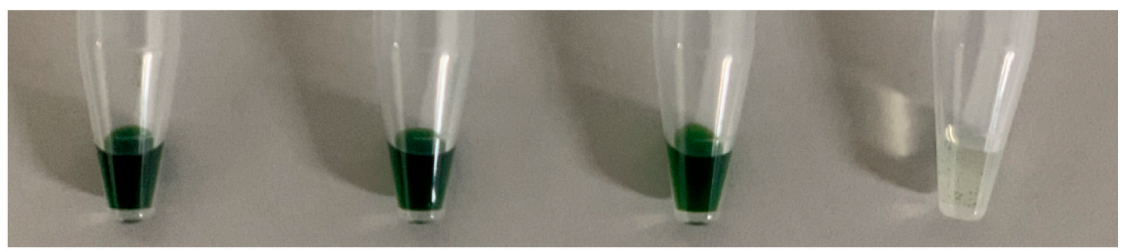

Figure 3. Comparison of the solution states of the PSI/DKDKC ${ }_{12} \mathrm{~K}-\mathrm{PA}_{n}$ conjugates and the reference supernatant solution of PSI. The PSI/DKDKC ${ }_{12} \mathrm{~K}-\mathrm{PA}_{n}$ conjugates were the isolated ones by removement of the unbound $\mathrm{DKDKC}_{12} \mathrm{~K}-\mathrm{PA}_{n}$ by gel permeation chromatography. The reference supernatant solution of PSI was prepared by decrease in $\beta$-DDM concentration less than $0.00001 \mathrm{wt} \%$ by ultrafiltration. (a) PSI/DKDKC ${ }_{12} \mathrm{~K}_{-} \mathrm{PA}_{5}$ conjugate, (b) PSI/DKDKC ${ }_{12} \mathrm{~K}-\mathrm{PA} \mathrm{A}_{7}$ conjugate, (c) PSI/DKDKC $12 \mathrm{~K}-\mathrm{PA}_{18}$ conjugate, $(\mathrm{d})$ the reference supernatant solution of PSI sample.

To characterize the conjugated structure and properties of the soluble state of PSI with $\mathrm{DKDKC}_{12} \mathrm{~K}-\mathrm{PA}_{n}$, we first analyzed the photophysical properties by UV-vis and fluorescence spectroscopy (Figure 4). As shown in Figure 4, all conjugates with $\mathrm{DKDKC}_{12} \mathrm{~K}$ $\mathrm{PA}_{5}, \mathrm{DKDKC}_{12} \mathrm{~K}-\mathrm{PA}_{7}$, and $\mathrm{DKDKC}_{12} \mathrm{~K}-\mathrm{PA}_{18}$ showed typical absorption peaks of PSI at 423 and $680 \mathrm{~nm}$ in Figure $4 \mathrm{a}$, similar to the case of solubilizing in a buffer with $0.1 \mathrm{wt} \%$ $\beta$-DDM (control of the native state) [20,21]. On the other hand, an increase in baseline, less than $600 \mathrm{~nm}$ region was also observed, which was different from that of solubilizing in a buffer with $0.1 \mathrm{wt} \% \mathrm{DKDKC}_{12} \mathrm{~K}_{-} \mathrm{PA}_{n}$, especially for the conjugates with $\mathrm{DKDKC}_{12} \mathrm{~K}$ $\mathrm{PA}_{5}$ and $\mathrm{DKDKC}{ }_{12} \mathrm{~K}-\mathrm{PA}_{7}$ (Figure $2 \mathrm{a}$ ). This suggests the formation of PSI aggregations. 
The fluorescence spectral peak at $720 \mathrm{~nm}$, derived from the red-chlorophyll state, was retained for all PSI samples. If the elimination of $\mathrm{Chl}$ a from the PSI scaffold occurred, its fluorescence peak should be observed at $680 \mathrm{~nm}$. However, no fluorescent peak at $680 \mathrm{~nm}$ was observed, suggesting that PSI maintained the native state in the conjugates.

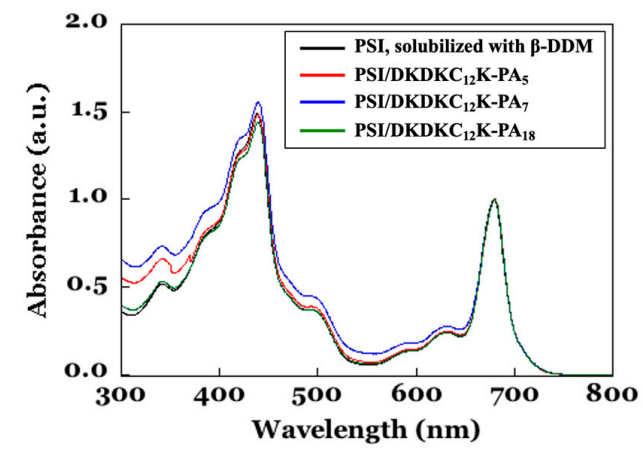

(a)

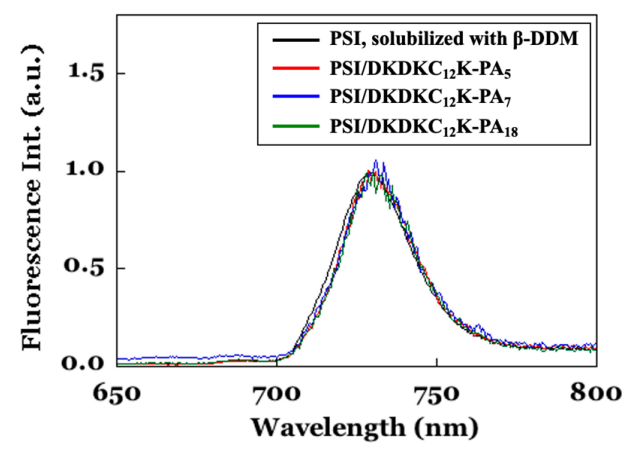

(b)

Figure 4. Absorption and fluorescence spectra of PSI, solubilized with $0.1 \mathrm{wt} \% \beta$-DDM, or conjugated with $\mathrm{DKDKC}_{12} \mathrm{~K}^{\mathrm{P}} \mathrm{PA}{ }_{n}$ $(n=5,7,18)$. (a) Absorption spectra of PSI, solubilized with $0.1 \mathrm{wt} \% \beta$-DDM (black), DKDKC ${ }_{12} \mathrm{~K}_{-}-\mathrm{PA}_{5}$ (red), $\mathrm{DKDKC}_{12} \mathrm{~K}-\mathrm{PA}{ }_{7}$ (blue), and $\mathrm{DKDKC}_{12} \mathrm{~K}_{-} \mathrm{PA}_{18}$ (green). (b) Florescence spectra of PSI, solubilized with $0.1 \mathrm{wt} \% \beta$-DDM (black), DKDKC ${ }_{12} \mathrm{~K}-$ $\mathrm{PA}_{5}$ (red), $\mathrm{DKDKC}_{12} \mathrm{~K}-\mathrm{PA}_{7}$ (blue), and $\mathrm{DKDKC}_{12} \mathrm{~K}-\mathrm{PA}_{18}$ (green).

The light-induced electron transfer activity of PSI is a useful probe to assess them and can be evaluated by concentration change in solubilized oxygen using an oxygen electrode. In the presence of $\mathrm{MV}^{2+}$ molecules in a solution, the electrons generated by photoexcitation at the $\mathrm{P}_{700}$ special pair first migrate following the potential gradients through phylloquinone and the [4Fe-4S] cluster sites $\left(F_{\mathrm{X}}, F_{\mathrm{A}}\right.$, and $\left.F_{\mathrm{B}}\right)$ and are finally trapped in $\mathrm{MV}^{2+}$ molecules in a solution. Because the dissolved oxygen immediately quenches the one-electron reductant of $\mathrm{MV}^{2+}$, the initial oxygen consumption rate can be considered identical to the initial rate of light-induced electron transfer in PSI [20,29]. After reducing the resultant hole at the special pair $\left(\mathrm{P} \mathrm{P0} 0^{+}\right)$by sodium ascorbate assisted by dichloroindophenol (DCIP), one sequential electron transfer process initiated by light irradiation is completed. If protein denaturation occurred, the passage of electron migration was also damaged. As a result, the electron transfer rate could be reduced. The electron transfer rates per single PSI unit were calculated from the background-subtracted oxygen consumption data, and the obtained initial rates are summarized in Table 3. Although covering the PSI surface with PA units might hamper electron transfer to the $\mathrm{MV}^{2+}$ and DCIP in a buffer, comparable electron transfer rates of those in a buffer with $0.1 \mathrm{wt} \% \beta$-DDM (control of the native state). This data also supported that PSI in the PSI/DKDKC ${ }_{12} \mathrm{~K}_{-} \mathrm{PA}_{n}$ conjugates maintain native characteristics, suggesting the maintenance of the tertiary structure of the membrane integral and the extracellular domains.

Table 3. Light-induced initial electron transfer rates in PSI solubilized with $0.1 \mathrm{wt} \% \beta$-DDM in a buffer or conjugated with $\mathrm{DKDKC}_{12} \mathrm{~K}-\mathrm{PA}_{5}, \mathrm{DKDKC}_{12} \mathrm{~K}-\mathrm{PA}_{7}$, or $\mathrm{DKDKC}_{12} \mathrm{~K}^{-\mathrm{PA}_{18}}$.

\begin{tabular}{cc}
\hline $\begin{array}{c}\text { Solubilization } \\
\text { Surfactant }\end{array}$ & $\begin{array}{c}\text { Electron Transfer Rate } \\
\text { in PSI (PSI } \mathbf{~ P S}^{-\mathbf{1}} \mathbf{~}^{\mathbf{a}}\end{array}$ \\
\hline$\beta-\mathrm{DDM}$ & $32.2 \pm 5.9$ \\
$\mathrm{DKDKC}_{12} \mathrm{~K}-\mathrm{PA}$ & $35.8 \pm 1.3$ \\
$\mathrm{DKDKC}_{12} \mathrm{~K}_{5}$ & $41.2 \pm 0.6$ \\
$\mathrm{DKDKC}_{12} \mathrm{~K}-\mathrm{PA}_{18}$ & $38.0 \pm 0.6$ \\
\hline
\end{tabular}

a Concentration of PSI solubilized with $0.001 \mathrm{wt} \%$ surfactant was $24 \mathrm{nM}$. A buffer containing $40 \mathrm{mM}$ HEPES- $\mathrm{NaOH}$ (pH 7.5), $100 \mathrm{mM} \mathrm{NaCl}, 15 \mathrm{mM} \mathrm{CaCl}, 15 \mathrm{mM} \mathrm{MgCl}_{2}$, and $0.4 \mathrm{M}$ sucrose supplemented with $0.5 \mathrm{mM}$ dichloroindophenol (DCIP), $2 \mathrm{mM}$ sodium ascorbate, and $0.5 \mathrm{mM} \mathrm{MV}^{2+}$ was used for oxygen uptake measurements. 
In order to examine the morphologies of the conjugates of PSI and DKDKC ${ }_{12} \mathrm{~K}_{-} \mathrm{PA}{ }_{n}$, we performed TEM observations. Each TEM sample was prepared by short adsorption of the conjugates onto the polyvinyl alcohol (PVA) layer-coated TEM grids and staining with sodium phosphotungstate. In the case of conjugates with $\mathrm{DKDKC}_{12} \mathrm{~K}^{\mathrm{PA}} \mathrm{A}_{5}$ and $\mathrm{DKDKC}_{12} \mathrm{~K}-$ $\mathrm{PA}_{7}$, the formation of plate-type 2D aggregations (less than $100 \mathrm{~nm}$ of wide and $\sim 7 \mathrm{~nm}$ thickness), orienting horizontally (blue enclosing regions and arrows) or perpendicularly (red enclosing regions and arrows) to the surface of the PVA layer was observed, as shown in the left and center low TEM images of Figure 5. On the other hand, the conjugates with $\mathrm{DKDKC}_{12} \mathrm{~K}_{-} \mathrm{PA}_{18}$ showed homogeneously dispersed spherical morphologies, having $\sim 20 \mathrm{~nm}$ diameter (purple enclosing regions and arrows) in the right low TEM images of Figure 5. From X-ray structural analysis, PSI is known to have a low columnar structure and a diameter of about $20 \mathrm{~nm}$ [29]. The reference TEM image of the PSI sample, prepared from the PSI solution in a buffer with $0.1 \mathrm{wt} \% \beta$-DDM, gave circular morphologies with a diameter of $\sim 20 \mathrm{~nm}$ (data not shown). This meant that the circular morphologies in the right low TEM images of Figure 5 correspond to the conjugate PSI portion. Upon solubilizing with $\mathrm{DKDKC}_{12} \mathrm{~K}_{-} \mathrm{PA}_{18}, \mathrm{DKDKC}_{12} \mathrm{~K}-\mathrm{PA}_{18}$ molecules bind the integral membrane domain of PSI and locate around PSI molecules. Therefore, the bound $\mathrm{DKDKC}_{12} \mathrm{~K}-\mathrm{PA}_{18}$ was expected to be located between the circular $\sim 20 \mathrm{~nm}$ morphologies with a lower height than the PSI.
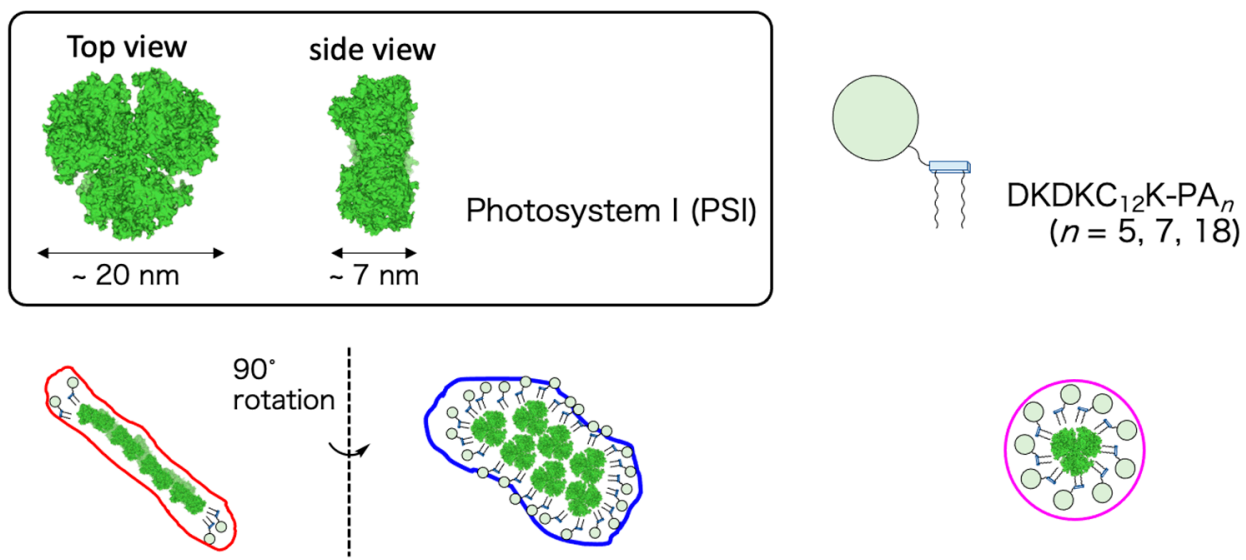

2D aggregates of PSI particles were solubilized by $\mathrm{DKDKC}_{12} \mathrm{~K}-\mathrm{PA}{ }_{5}$ or $\mathrm{DKDKC}_{12} \mathrm{~K}-\mathrm{PA}{ }_{7}$.
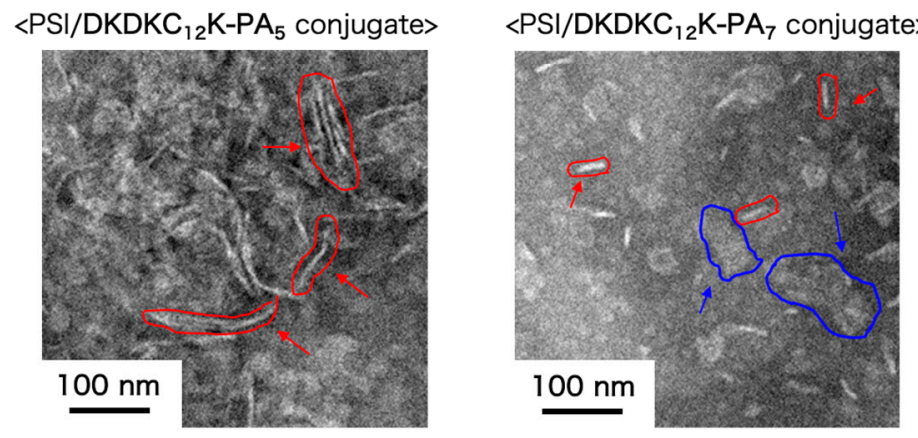
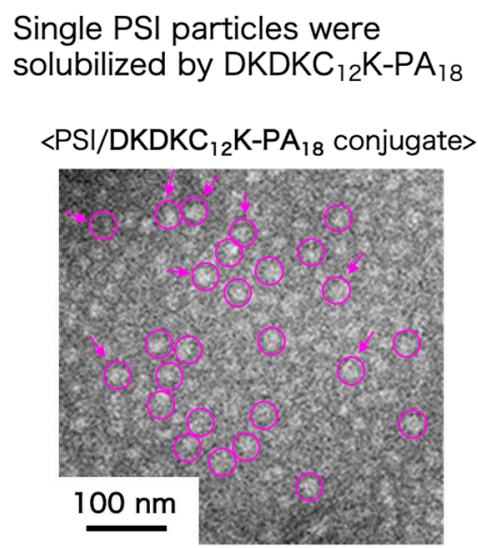

Figure 5. TEM images of the isolated PSI/DKDKC ${ }_{12} \mathrm{~K}-\mathrm{PA}_{n}$ conjugates (PSI/DKDKC ${ }_{12} \mathrm{~K}-\mathrm{PA}_{5}$ conjugates (left low), PSI/DKDKC ${ }_{12} \mathrm{~K}_{-} \mathrm{PA}_{7}$ conjugates (center low), and PSI/DKDKC ${ }_{12} \mathrm{~K}_{-} \mathrm{PA}_{18}$ conjugates (right low)) and the schematic illustrations of the expected molecular structures of aggregates, observed in TEM images (upper). 2D aggregates of PSI particles solubilized with $\mathrm{DKDKC}_{12} \mathrm{~K}_{-} \mathrm{PA}_{5}$ or $\mathrm{DKDKC}_{12} \mathrm{~K}-\mathrm{PA}_{7}$ are indicated by red or blue enclosing regions and arrows. While single PSI particles solubilized with $\mathrm{DKDKC}_{12} \mathrm{~K}-\mathrm{PA}_{18}$ are indicated by purple enclosing regions and arrows. Accelerate voltage, $200 \mathrm{kV}$.

Based on the morphologies and rigorous assessments of the photophysical properties, we found that $\mathrm{DKDKC}_{12} \mathrm{~K}-\mathrm{PA}_{18}$ is the best PA-appended PG-surfactant among the other 
DKDKC $_{12} \mathrm{~K}_{-\mathrm{PA}}$ studied, solubilizing PSI in a surfactant-free buffer without inducing PSI aggregation and denaturation.

\section{Materials and Methods}

\subsection{Materials}

Rink-amide AM resin (200-400 mesh) was purchased from Merck Biosciences (Darmstadt, Germany). N-(9-fluorenylmethoxycarbonyl) (Fmoc)-protected-amino acids, 1-hydrox ybenzotriazole (HOBT), 2-(1H-benzotriazole-1-yl)-1,1,3,3-tetramethyluronium hexafluorophosphate (HBTU), N,N-diisopropylethylamine (DIEA), piperidine, trifluoroacetic acid (TFA), and N-methyl pyrrolidone (NMP) were purchased from Watanabe Chemical Industries (Hiroshima, Japan). Acrylamide and VA-057 were purchased from Wako Pure Chemical Industries, Ltd. (Osaka, Japan). Poly(ethylene glycol) average $M_{\mathrm{n}}=1500 \mathrm{~g} / \mathrm{mol}$ (PEG1500), $n$-dodecyl- $\beta$-D-maltopyranoside ( $\beta$-DDM), dichloroindophenol (DCIP), $L(+)$ Ascorbic Acid Sodium Salt, and methyl viologen dichloride dihydrate $\left(\mathrm{MV}^{2+}\right)$ were purchased from Sigma-Aldrich (St. Louis, MO, USA). The RAFT initiator containing the dithiopyridyl (DTP) group, BSTP pyridyl disulfide, was synthesized according to previous study [27]. PSI derived from T. vulcanus was prepared similar to the previous study [21]. Unless otherwise stated, other chemicals and reagents were obtained commercially and used without further purification. BSTP disulfide was synthesized as following the previous study.

\subsection{Synthesis of $P G$-Surfactant, $D K D K C_{12} K C$}

PG-surfactant, DKDKC ${ }_{12} \mathrm{KC}$, was synthesized on a Rink-amide AM resin using commercially available Fmoc-protected amino acids and our synthesized Fmoc-Cys $\left(\mathrm{C}_{12}\right)$ $\mathrm{OH}$ [19]. For condensation onto the resin, standard coupling reagents (HOBT/HBTU/DIEA) were used. The $\mathrm{N}$-terminus of PG-surfactants was end-capped with $\mathrm{Ac}_{2} \mathrm{O}$. After cleavage of the synthesized PG-surfactants from the resin using TFA $/ \mathrm{H}_{2} \mathrm{O}(95 / 5)$, the crude PGsurfactants were purified by reversed-phase high-performance liquid chromatography (RPHPLC) with a core-shell-type ODS column (Kinetex, Shimadzu, Japan). A linear-gradient of $\mathrm{CH}_{3} \mathrm{CN}$ and $\mathrm{H}_{2} \mathrm{O}$, both including $0.1 \mathrm{vol} \%$ TFA, was utilized as eluent (Figure S1a). Product identification was checked by high-resolution ESI-TOF (electrospray ionization time-of-flight) mass spectroscopy (Figure $\mathrm{S} 1 \mathrm{~b}$ ).

DKDKC ${ }_{12} \mathrm{KC}$ : HRMS (ESI-TOF, $[\mathrm{M}+\mathrm{H}]^{+}$): calcd. for $\mathrm{C}_{68} \mathrm{H}_{128} \mathrm{~N}_{15} \mathrm{O}_{15} \mathrm{~S}_{2}, 1433.8298$; found, 1433.8282 .

3.3. Synthesis of Polyacrylamide Having Dithiopyridyl Terminal Group $\left(P A_{n}-D T P, n=5,7,18\right)$ by RAFT Polymerization

$\mathrm{PA}_{n}$-DTP $\left(n=5,7,18, M_{\mathrm{n}}=5,7,18 \mathrm{kDa}\right)$, having 2-pyridyldisulfide groups at the terminal, were synthesized by the RAFT technique with molar ratio of monomer/initiator/BSTP pyridyl disulfide [27] of $1124 / 1 / 2$ for PA (18 kDa), 562/1/2 for PA (7 kDa), and $281 / 1 / 2$ for PA (5 kDa). For instance, PA (18 kDa) was synthesized as follows. AM $(2.00 \mathrm{~g}, 28.1 \mathrm{mmol})$, VA-057 (10.4 mg, $25.0 \mu \mathrm{mol})$, and BSTP pyridyl disulfide $(22.1 \mathrm{mg}, 50.0 \mu \mathrm{mol})$ were dissolved in DMSO $/ \mathrm{H}_{2} \mathrm{O}(5: 3,16 \mathrm{~mL})$ in a round-bottom flask and sealed with a septum. The flask was degassed by freeze thawing with nitrogen and subsequently placed in a preheated hot-bath at $50{ }^{\circ} \mathrm{C}$ for $105 \mathrm{~min}$. The resulting polymer was precipitated 3 times from acetone and dried in vacuo. Yield: $1.41 \mathrm{~g}(71 \%)$. The $M_{\mathrm{n}}$ and polydispersity index (PDI) of the synthesized polymers were estimated by a gel permeation chromatography (GPC), respectively. These estimated data of $M_{n}$ and PDI were summarized in Table 1.

\subsection{Synthesis of the PA(5, 7, $18 \mathrm{kDa})$-Appended DKDKC ${ }_{12} K C, D K D K C_{12} K-P A_{n}(n=5,7,18)$}

To a $\mathrm{N}_{2}$-substituted water ( $\left.3 \mathrm{~mL}\right)$, PA with dithiopyridyl group $\left(M_{\mathrm{n}}=5,7,18 \mathrm{kDa}\right.$, $7 \mathrm{mmol})$ and $\mathrm{DKDKC}_{12} \mathrm{KC}(3.0 \mathrm{mg}, 3.5 \mu \mathrm{mol})$ was added and it was stirred for $2 \mathrm{~h}$. at ambient temperature. It was purified by RP-HPLC with a core-shell-type ODS column (Kinetex, Shimadzu, Japan). A linear-gradient of $\mathrm{CH}_{3} \mathrm{CN}$ and $\mathrm{H}_{2} \mathrm{O}$, both including $0.1 \mathrm{vol} \% \mathrm{TFA}$, was 
utilized as eluent. The HPLC profiles of $\operatorname{DKDKC}_{12} \mathrm{~K}-\mathrm{PA}_{n}(n=5,7,18)$ were summarized in Figures S2-S4.

\subsection{Dynamic Light Scattering Measurements of PG-Surfactant Assemblies}

The concentrations of each DKDKC ${ }_{12} \mathrm{~K}_{-} \mathrm{PA}_{n}(n=5,7,18)$ in $100 \mathrm{mM}$ phosphate buffer ( $\mathrm{pH} 7$ ) were set at $0.1 \mathrm{wt} \%$ and the mean hydrodynamic diameters of PG-surfactant assemblies for each concentration at $25{ }^{\circ} \mathrm{C}$ were estimated using a Zetasizer Nano ZS (Malvern Instruments, Ltd., Malvern, UK).

3.6. Critical Aggregation Concentration (CAC) Determination for PG-Surfactants Using 8-Anilino-Naphtharene-1-Sulfonic Acid (ANS)

The CACs of $\mathrm{DKDKC}_{12} \mathrm{~K}_{-} \mathrm{PA}_{n}(n=5,7,18)$ in $100 \mathrm{mM}$ phosphate buffer $(\mathrm{pH} 7)$ were evaluated by the fluorescent method [30] similar to the previous studies $[20,21,23]$.

\subsection{Replacement of Solubilization Surfactant via PEG Precipitation}

The PSI sample, solubilized with DKDKC ${ }_{12} \mathrm{~K}^{-\mathrm{PA}}{ }_{n}(n=5,7,18)$ in the buffer $\mathrm{K} 2[40 \mathrm{mM}$ HEPES-NaOH (pH 7.8), $100 \mathrm{mM} \mathrm{NaCl}, 15 \mathrm{mM} \mathrm{CaCl}_{2}$, and $15 \mathrm{mM} \mathrm{MgCl}{ }_{2}$ ], containing $0.1 \mathrm{wt} \%$ of $\mathrm{DKDKC}_{12} \mathrm{~K}_{-\mathrm{PA}}(n=5,7,18)$ was prepared similar to the previous studies $[20,21]$.

\subsection{Isolation of the Conjugates of PSI and $D K D K C_{12} K-P A_{n}(n=5,7,18)$}

The unbound-DKDKC ${ }_{12} \mathrm{~K}_{-}-\mathrm{PA}_{n} \mathrm{~s}(n=5,7,18)$ were first removed by ultrafiltration (Amicon Ultra $0.5 \mathrm{~mL}$ Centrifugal Filters, Devise NMWL $100 \mathrm{kDa}$ ) for the PSI sample, solubilized with DKDKC ${ }_{12} \mathrm{~K}_{-} \mathrm{PA}_{n}(n=5,7,18)$ in the buffer K2 $(40 \mathrm{mM}$ HEPES-NaOH ( $\mathrm{pH}$ 7.8), $100 \mathrm{mM} \mathrm{NaCl}, 15 \mathrm{mM} \mathrm{CaCl}_{2}$, and $15 \mathrm{mM} \mathrm{MgCl}_{2}$ ). Then these were subjected to gel permeation chromatography $(1 \mathrm{~cm}$ (i.d.) $\times 30 \mathrm{~cm}(\mathrm{~h})$, Superose 6, GE Healthcare, Milwaukee, WI, USA) was applied using the buffer K2 as an eluent.

\subsection{Evaluation of Photo-Induced Electron-Transfer Rate of PSI Based on Decreases in $\mathrm{O}_{2}$ Concentration}

Measurements of the $\mathrm{O}_{2}$ uptake rate to evaluate photo-induced initial electron transfer rate of PSI were conducted at $25^{\circ} \mathrm{C}$ using a Clark-type $\mathrm{O}_{2}$ electrode (Hansatech Instruments, DW1, Oxygen Electrode Unit; Norfolk, VA, USA), similar to the previous study [20,21].

\subsection{Fluorescence Spectrum of PSI at $77 \mathrm{~K}$}

The fluorescence spectrum of the conjugates of PSI and $\mathrm{DKDKC}_{12} \mathrm{~K}_{-\mathrm{PA}}(n=5,7,18)$ in the buffer K2 was observed similar to the previous study [20,21].

\subsection{TEM Measurements of the Conjugates of PSI and DKDKC ${ }_{12} K-P A_{n}(n=5,7,18)$}

TEM images were obtained with JEM-z2500 (JEOL). All the samples were prepared by dry-cast of protein solutions supported on a poval-coated Cu grid (400 mesh, Okenshoji Co., Ltd., Tokyo, Japan). Membrane protein concentration was $5 \mu \mathrm{g} \mathrm{Chla/mL} \mathrm{of} \mathrm{the} \mathrm{isolated} \mathrm{PSI}$ conjugates with $\mathrm{DKDKC}_{12} \mathrm{~K}-\mathrm{PA}_{n}(n=5,7,18)$. This solution was dropped on the $\mathrm{Cu}$ grid and left to stand for approximately $5 \mathrm{~min}$ at room temperature. Droplets were removed with filter paper and stained by sodium phosphotungstate solution $(2 \mathrm{wt} \%)$ in pure water. This sample was rinse three times with pure water.

\section{Conclusions}

In this study, we constructed PA-modified PG-surfactants, DKDKC ${ }_{12} \mathrm{~K}_{-} \mathrm{PA}_{n}$, and examined its ability to solubilize membrane proteins. All surfactants could solubilize PSI in a buffer containing $0.1 \mathrm{wt} \%$ of each surfactant without any denaturation. However, under surfactant-free conditions (i.e., after removal of the unbound surfactants from the sample solution), the ability to solubilize PSI in a buffer was different; DKDKC ${ }_{12} \mathrm{~K}$ $\mathrm{PA}_{5}$ and $\mathrm{DKDKC}{ }_{12} \mathrm{~K}-\mathrm{PA}{ }_{7}$ could solubilize PSI in a surfactant-free buffer without protein denaturation, but several PSI aggregations were observed. In contrast, $\mathrm{DKDKC}_{12} \mathrm{~K}^{-\mathrm{PA}_{18}}$ could solubilize PSI without inducing protein denaturation and aggregation. This should 
be reasoned by the difference in affinity of PA chains, concentrated onto PSI surfaces; PA chains with $18 \mathrm{kDa}$ of $\mathrm{Mn}$ had enough affinity without inducing elimination of $\mathrm{DKDKC}_{12} \mathrm{~K}$ $\mathrm{PA}_{18}$ molecules from the PSI surface.

Supplementary Materials: Supplementary Materials can be found at https://www.mdpi.com/ 1422-0067/22/4/1524/s1. Figure S1: Purification of PG-surfactant, DKDKC ${ }_{12}$ KC, Figure S2: Purification of PA-modified PG-surfactant, $\mathrm{DKDKC}_{12} \mathrm{~K}^{\mathrm{P}} \mathrm{P}_{5}$, Figure S3: Purification of PA-modified PG-surfactant, DKDKC ${ }_{12} \mathrm{~K}_{-} \mathrm{PA}$, Figure S4: Purification of PA-modified PG-surfactant, DKDKC ${ }_{12} \mathrm{~K}-$ $\mathrm{PA}_{18}$, Figure S5: Change in $F_{478}$ of 8-anilino-1-naphthalene sulfonate (ANS) in accordance with increased concentration of $\mathrm{DKDKC}_{12} \mathrm{~K}_{-} \mathrm{PA}_{5}$.

Author Contributions: Conceptualization, T.M.; investigation, T.S., T.N. (Tatsuki Nakakubo), T.N. (Tomoyasu Noji), S.K., K.K., N.K.; writing—original draft preparation, T.S.; writing-review and editing, T.M.; supervision, T.M.; project administration, T.M.; funding acquisition, T.M. All authors have read and agreed to the published version of the manuscript.

Funding: This work was supported by JSPS KAKENHI (Grant Numbers 20K05705), the Takahashi Industrial and Economic Research Foundation, and Ichihara International scholarship foundation.

Acknowledgments: We thank Makoto Miyata and Yu-hei Tahara, affiliated with the Department of Biology, Graduate School of Science, Osaka City University, for technical assistance with TEM measurements of the PSI/DKDKC ${ }_{12} \mathrm{~K}_{-} \mathrm{PA}_{n}$ conjugates $(n=5,7,18)$.

Conflicts of Interest: The authors declare no conflict of interest.

\section{References}

1. Dekkera, J.P.; Boekema, E.J. Supramolecular organization of thylakoid membrane proteins in green plants. Biochim. Biophys. Acta 2005, 1706, 12-39. [CrossRef]

2. Marco, P.; Elman, T.; Yacoby, I. Binding of ferredoxin NADP ${ }^{+}$oxidoreductase (FNR) to plant photosystem I. Biochim. Biophys. Acta Bioenergy 2019, 1860, 689-698. [CrossRef]

3. Utschig, L.M.; Soltau, S.R.; Mulfort, K.L.; Niklas, J.; Poluektov, O.G. Z-Scheme solar water splitting via self-assembly of photosystem I-catalyst hybrids in thylakoid membranes. Chem. Sci. 2018, 9, 8504-8512. [CrossRef]

4. Ciesielski, P.N.; Scott, A.M.; Faulkner, C.J.; Berron, B.J.; Cliffel, D.E.; Jennings, G.K. Functionalized nanoporous gold leaf electrode films for the immobilization of photosystem I. ACS Nano 2008, 23, 2465-2472. [CrossRef]

5. Utschig, L.M.; Silver, S.C.; Mulfort, K.L.; Tiede, D.M. Nature-Driven photochemistry for catalytic solar hydrogen production: A photosystem I-Transition metal catalyst hybrid. J. Am. Chem. Soc. 2011, 133, 16334-16337. [CrossRef]

6. Zhao, F.; Conzuelo, F.; Hartmann, V.; Li, H.; Nowaczyk, M.M.; Plumere, N.; Rögner, M.; Schuhmann, W. Light induced $\mathrm{H}_{2}$ evolution from a biophotocathode based on photosystem 1-Pt nanoparticles complexes integrated in solvated redox polymers films. J. Phys. Chem. B 2015, 119, 13726-13731. [CrossRef]

7. Ihara, M.; Nishihara, H.; Yoon, K.; Lenz, O.; Friedrich, B.; Nakamoto, H.; Kojima, K.; Honma, D.; Kamachi, T.; Okura, I. LightDriven hydrogen production by a hybrid complex of a [NiFe]-Hydrogenase and the cyanobacterial photosystem I. Photochem. Photobiol. 2006, 82, 676-682. [CrossRef]

8. Grimme, R.A.; Lubner, C.E.; Bryant, D.A.; Golbeck, J.H. Photosystem I/Molecular wire/metal nanoparticle bioconjugates for the photocatalytic production of $\mathrm{H}_{2}$. J. Am. Chem. Soc. 2008, 130, 6308-6309. [CrossRef]

9. Nguyen, K.; Bruce, B.D. Growing green electricity: Progress and strategies for use of photosystem I for sustainable photovoltaic energy conversion. Biochim. Biophys. Acta 2014, 1837, 1553-1566. [CrossRef]

10. Ciornii, D.; Riedel, M.; Stieger, K.R.; Feifel, S.C.; Hejazi, M.; Lokstein, H.; Zouni, A.; Lisdat, F. Bioelectronic circuit on a 3D electrode architecture: Enzymatic catalysis interconnected with photosystem I. J. Am. Chem. Soc. 2017, 139, 16478-16481. [CrossRef]

11. Misawa, N.; Fujii, S.; Kamiya, K.; Osaki, T.; Takaku, T.; Takahashi, Y.; Takeuchi, S. Construction of a biohybrid odorant sensor using biological olfactory receptors embedded into bilayer lipid membrane on a chip. ACS Sens. 2019, 4, 711-716. [CrossRef] [PubMed]

12. Nield, J.; Morris, E.P.; Bibby, T.S.; Barber, J. Structural analysis of the photosystem I supercomplex of cyanobacteria induced by iron deficiency. Biochemistry 2003, 42, 3180-3188. [CrossRef] [PubMed]

13. Elter, S.; Raschle, T.; Arens, S.; Viegas, A.; Gelev, V.; Etzkorn, M.; Wagner, G. The use of amphipols for NMR structural characterization of 7-TM proteins. J. Membr. Biol. 2014, 247, 957-964. [CrossRef] [PubMed]

14. Chae, P.S.; Rasmussen, S.G.F.; Rana, R.; Gotfryd, K.; Chandra, R.; Goren, M.A.; Kruse, A.C.; Nurva, S.; Loland, C.J.; Pierre, Y.; et al. Maltose-Neopentyl glycol (MNG) amphiphiles for solubilization, stabilization and crystallization of membrane proteins. Nat. Methods 2010, 7, 1003-1008. [CrossRef] [PubMed]

15. Tribet, C.; Audebert, R.; Popot, J.-L. Amphipols: Polymers that keep membrane proteins soluble in aqueous solutions. Proc. Natl. Acad. Sci. USA 1996, 93, 15047-15050. [CrossRef] [PubMed] 
16. Dörr, J.M.; Koorengevel, M.C.; Schäfer, M.; Prokofyev, A.V.; Scheidelaar, S.; Cruijsen, E.A.W.; Dafforn, T.R.; Baldus, M.; Killian, J.A. Detergent-Free isolation, characterization, and functional reconstitution of a tetrameric $\mathrm{K}^{+}$channel: The power of native nanodiscs. Proc. Natl. Acad. Sci. USA 2014, 111, 18607-18612. [CrossRef] [PubMed]

17. Barniol-Xicota, M.; Verhelst, S.H.L. Stable and functional rhomboid proteases in lipid nanodiscs by using diisobutylene/maleic acid copolymers. J. Am. Chem. Soc. 2018, 140, 14557-14561. [CrossRef] [PubMed]

18. Zhang, M.; Huang, R.; Ackermann, R.; Im, S.-C.; Waskell, L.; Schwendeman, A.; Ramamoorthy, A. Reconstitution of the Cytb5CytP450 complex in nanodiscs for structural studies using NMR spectroscopy. Angew. Chem. Int. Ed. 2016, 55, 4497-4499. [CrossRef] [PubMed]

19. Umezaki, K.; Sakai, S.; Koeda, S.; Yamamoto, Y.; Kondo, M.; Ikeda, A.; Dewa, T.; Taga, K.; Tanaka, T.; Mizuno, T. Formation of planar bilayer membranes on solid supports using peptide gemini surfactants. Chem. Lett. 2012, 41, 1430-1432. [CrossRef]

20. Koeda, S.; Umezaki, K.; Noji, T.; Ikeda, A.; Kawakami, K.; Kondo, M.; Yamamoto, Y.; Shen, J.R.; Taga, K.; Dewa, T.; et al. Application of peptide gemini surfactants as novel solubilization surfactants for photosystems I and II of cyanobacteria. Langmuir 2013, 29, 11667-11680. [CrossRef]

21. Koeda, S.; Suzuki, T.; Noji, T.; Kawakami, K.; Itoh, S.; Dewa, T.; Kamiya, N.; Mizuno, T. Rational design of novel high molecular weight solubilization surfactants for membrane proteins from the peptide gemini surfactants (PG-Surfactants). Tetrahedron 2016, 72, 6898-6908. [CrossRef]

22. Shibata, M.; Koeda, S.; Noji, T.; Kawakami, K.; Ido, Y.; Amano, Y.; Umezawa, N.; Higuchi, T.; Dewa, T.; Itoh, S.; et al. Design of new extraction surfactants for membrane proteins from peptide gemini surfactants. Bioconjug. Chem. 2016, 27, 2469-2479. [CrossRef]

23. Taniguchi, A.; Koeda, S.; Noji, T.; Kawakami, K.; Sumito, N.; Dewa, T.; Itoh, S.; Kamiya, N.; Mizuno, T. Synthesis and characterization of chemically-reactive solubilization surfactants for membrane proteins and preparation of membrane protein hydrogel microfibers. Colloid Interface Sci. Commun. 2019, 32, 100199. [CrossRef]

24. Reisinger, V.; Eichacker, L.A. Analysis of membrane protein complexes by blue native PAGE. Proteomics 2006, 6 (Suppl. 2), 6-15. [CrossRef]

25. Sassolas, A.; Hayat, A.; Marty, J.-L. Enzyme immobilization by entrapment within a gel network. Methods Mol. Biol. 2013, 1051, 229-239. [PubMed]

26. McCormick, C.L.; Lowe, A.B. Aqueous RAFT polymerization: Recent developments in synthesis of functional water-soluble (co)polymers with controlled structures. Acc. Chem. Res. 2004, 37, 312-325. [CrossRef] [PubMed]

27. Liu, J.; Bulmus, V.; Herlambang, D.L.; Barner-Kowollik, C.; Stenzel, M.H.; Davis, T.P. In situ formation of protein-polymer conjugates through reversible addition fragmentation chain transfer polymerization. Angew. Chem. Int. Ed. 2007, 46, 3099-3103. [CrossRef]

28. Jordan, P.; Fromme, P.; Witt, H.T.; Klukas, O.; Saenger, W.; Krauû, N. Three-Dimensional structure of cyanobacterial photosystem I at 2.5 A resolution. Nature 2001, 411, 909-917. [CrossRef] [PubMed]

29. Shen, J.R. Denshidentatsu kassei. Low Temp. Sci. 2009, 67, 551-560.

30. De Vendittis, E.; Palumbo, G.; Parlato, G.; Bocchini, V. A fluorimetric method for the estimation of the critical micelle concentration of surfactants. Anal. Biochem. 1981, 115, 278-286. [CrossRef] 